\title{
UPAYA MEMAKSIMALKAN HASIL BELAJAR BAHASA DAN SASTRA INDONESIA MELALUI PENERAPAN MOTIVASI, DENGAN METODE BERMAIN PERAN DAN SOSIO DRAMA SISWA KELAS XII IPS 1 DI SMA NEGERI 2 BANGKO
}

(The Efforts to Maximize Indonesian Language and Literature Learning Outcomes through Motivation Application, with Role Play and Sosio Drama Methods of XII IPS 1 Students in SMA Negeri 2 Bangko)

\section{Oleh: Rina Angriani*)}

*) Guru SMA Negeri 2 Bangko Kabupaten Rokan Hilir

\begin{abstract}
The purpose of this study is to improve learning outcomes in Indonesian subjects on the component of the ability of literary aspects of speaking, basic competence to express the dialogue of the characters in the play, knowing the effectiveness of the application of motivation, role playing methods, and socio drama, in improving learning outcomes subjects Bahasa Indonesia, the component of the ability of bersasra, the aspect of basic competence to express the dialogue of the character's role in the drama performance, to know the influence of the application of motivation, the role playing method and the socio-drama, express the dialogue of the characters in the staging of the drama of the class XII IPS1 SMA Negeri 2 Bangko to improve the learning result of the eye Bahasa Indonesia component of literary ability, basic competence speaking aspect expressed the dialogue of the characters in the drama performance. This study uses a classroom action research design (PTK). The subjects of the study were students of SMA Negeri 2 Bangko Kabupaten Rokan Hilir The research procedure used Kemmis and Taggart model, consisting of planning, action and observation, and reflection. Technique of data taker through learning result data, learning data. The data that have been obtained are grouped, analyzed by using analysis of minimum learning mastery criteria. The research results: 1) The application of motivational approach, with role playing method and socio drama can maximize or improve learning outcomes, Indonesian subjects, component of literary ability of speaking aspect expressing dialogue of the characters in drama 2) Implementation of motivational approach, by role playing method and socio can cause a sense of appreciation of the art of staging drama in the learning of Indonesian subjects, the component of the ability of literary aspects of speaking basic competence to express the dialogue of the characters in staging drama. 3) The application of motivational approach, by role playing method and socio drama can improve cooperation and mutual respect among students in learning Indonesian subjects, component of literary ability of speaking aspect of basic competence expressing dialogue of the characters in staging drama.
\end{abstract}

Keywords: Learning outcomes, Indonesia language, motivation, role playing, socio drama.

\section{PENDAHULUAN}

Kehidupan manusia tidak dapat dilepaskan dari bahasa. Bahasa merupakan sarana untuk berkomunikasi antarmanusia. Bahasa sebagai alat komunikasi ini dalam rangka memenuhi sifat manusia sebagai makhluk sosial yang perlu berinteraksi dengan sesama manusia.

Hasil belajar dapat dilihat dari terjadinya perubahan hasil masukan pribadi berupa motivasi dan harapan untuk berhasil (Keller dalam Nashar, 2004:77). Masukan itu berupa rancangan dan pengelolaan motivasional yang tidak berpengaruh langsung terhadap besarnya usaha yang dicurahkan oleh siswa untuk mencapai tujuan belajar. Perubahan itu terjadi pada seseorang dalam disposisi atau kecakapan manusia yang berupa penguasaan ilmu pengetahuan dan keterampilan yang diperoleh melalui usaha yang sungguhsungguh dilakukan dalam satu waktu tertentu atau dalam waktu yang relatif lama.

Hasil belajar yang diharapkan biasanya berupa prestasi belajar yang baik 
atau optimal. Namun dalam pencapaian hasil belajar yang baik masih saja mengalami kesulitan dan prestasi yang didapat belum dapat dicapai secara optimal. Dalam peningkatan hasil belajar siswa dipengaruhi oleh banyak faktor, salah satunya yakni motivasi untuk belajar.

Dalam upaya peningkatan kualitas pembelajaran berbagai upaya dilakukan yaitu dengan peningkatan motivasi belajar. Atkinson dan Feather dalam Soemanto (1989:189) menyatakan jika motivasi siswa untuk berhasil lebih kuat daripada motivasi untuk tidak gagal, maka ia akan segera memerinci kesulitan-kesulitan yang dihadapinya. Sebaliknya ia akan mencari soal yang lebih mudah atau bahkan yang lebih sukar.

Setelah diadakan ulangan harian pada semester 2 terhadap siswa kelas XII IPS 1 SMA Negeri 2 Bangko tahun pelajaran 2014/2015 hasil belajar komponen kemampuan bersastra aspek berbicara hanya 36\% yang memperoleh diatas 65. Hal ini disebabkan, saat ini sebagian besar guru dalam mengajar masih menggunakan komunikasi satu arah. Dengan cara mengajar seperti ini, guru bertindak sebagai pemberi ilmu pengetahuan, sedangkan siswa dinaggap sebagai penerima pengetahuan yang pasif (Setiawan, 2004:28).

Sehubungan dengan itu perlu adanya perbaikan pembelajaran mata pelajaran Bahasa Indonesia komponen kemampuan bersastra, aspek berbicara, dengan kompetensi dasar mengekspresikan dialog para tokoh dalam pementasan drama pada siswa kelas XII IPS 1 dengan jumlah siswa sebanyak 33 orang semester 1 pelajaran ini berbentuk penelitian tindakan kelas.

Penelitian tindakan kelas ini, menerapkan motivasi dan metode bermain peran, dan sosio drama dapat meningkat hasil belajar Bahasa Indonesia komponen kemamapuan bersastra, aspek berbicara, dengan kompetensi dasar mengekspresikan dialog para tokoh dalam pementasan drama.

\section{METODE PENELITIAN}

Penelitian ini berbentuk penelitian tindakan kelas.. Prosedur penelitian menggunakan model Kemmis dan Taggart, terdiri dari tahap perencanaan, tindakan dan pengamatan, serta refleksi. Penelitian ini terdiri dari tiga Siklus yakni Siklus I, Siklus II dan Siklus III.

Penelitian ini diadakan di SMA Negeri 2 Bangko, pada kelas XII IPS yang terdiri dari 4 kelas dengan jumlah siswa 286 orang.

\section{HASIL PENELITIAN DAN PEMBAHASAN \\ Perbaikan \\ pelaksanaan} pembelajaran dengan penerapan motivasi, metode bermain peran, dan metode rasio drama mata pelajaran Bahasa Indonesia komponen kemempuan bersastra aspek berbicara kompetensi dasar mengekspresikan dialog para tokoh dalam pementasan drama memperlihatkan hasil belajar siswa yang sangat baik, baik aspek penilaian kognetif, psikomotor, maupun efektif. Hal ini ada kenaikan hasil belajar siswa dari pembelajaran antar siklus baik aspek kognetif, psikomotor, maupun aspek afektif untuk lebih jelasnya dapat dilihat pada grafik berikut:

\section{Grafik Hasil Belajar Aspek Kognitif}

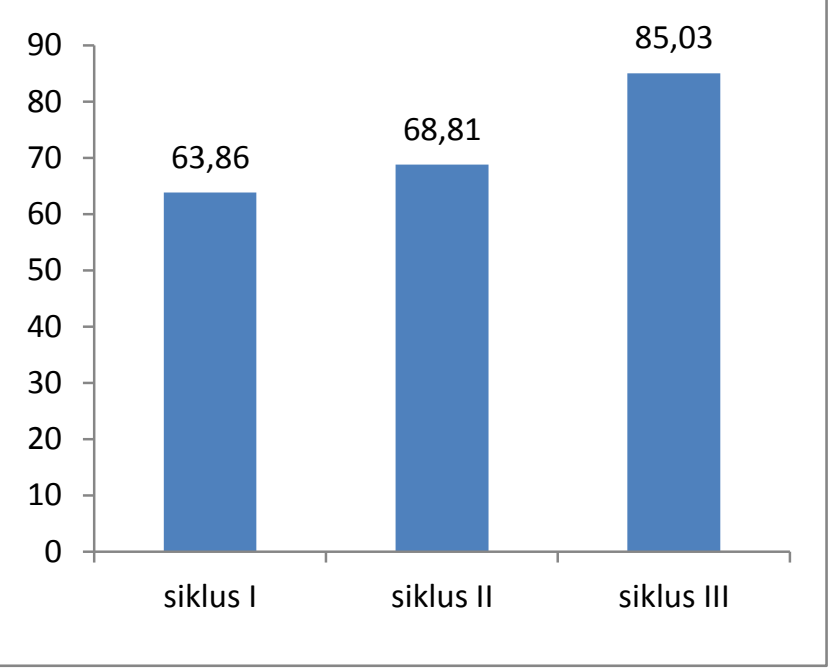



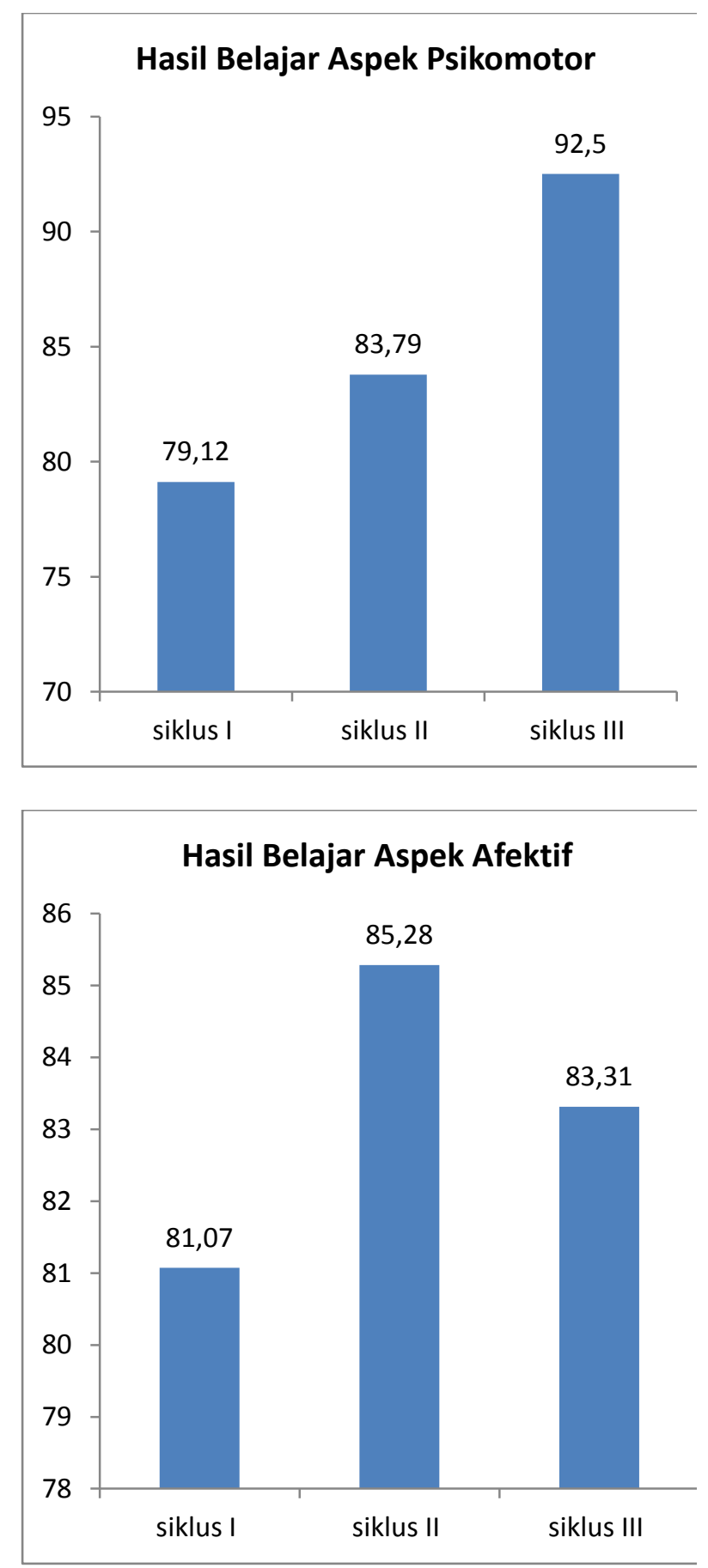

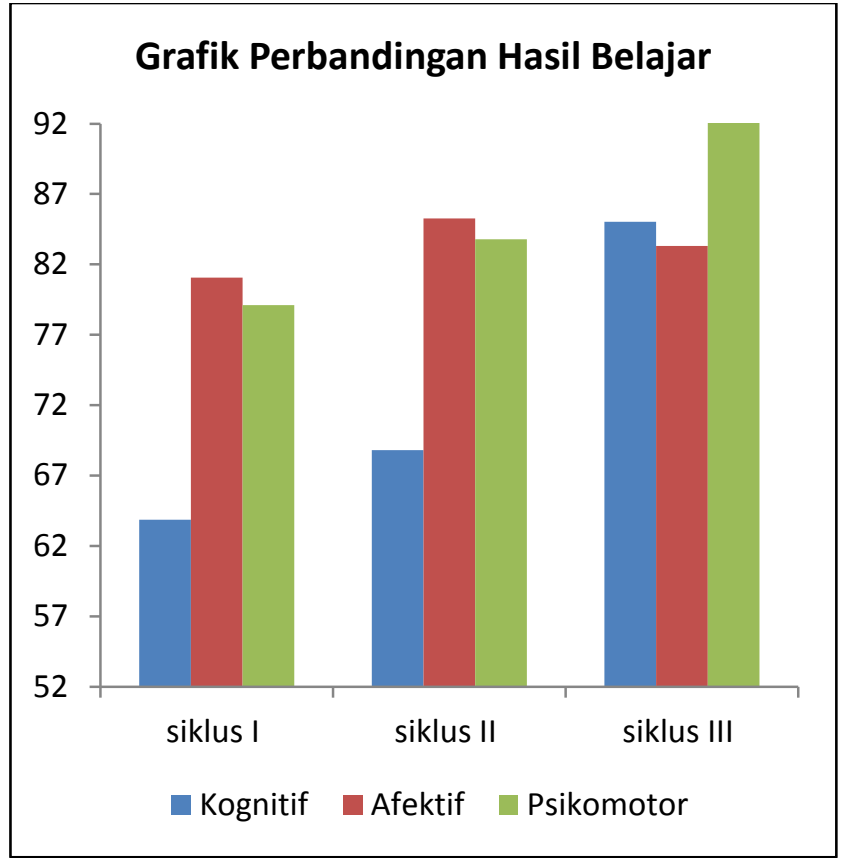

Penelitian tindakan kelas dengan menerapkan motivasi, dengan metode bermain peran dan sosio drama mengekspresikan dialog para tokoh pementasan drama, dengan penilaian aspek kognitif, aspek psikomotor dan aspek afektif dihasilkan temuan sebagai berikut :

1. Meningkatkan motivasi belajar siswa dalam pembelajaran dengan penerapan berperan, sehingga kelas menjadi kelas yang aktif, dan kreatif

2. Siswa belajar dalam suasana menyenangkan, dan menggembirakan

3. Siswa merasa bertanggung jawab dalam, sesuai dengan peran dan fungsinya dalam kelas

4. Pemahaman siswa bertambah terhadap materi pembelajaran

5. Dengan pembelajaran motivasi dengan metode bermain peran dan sosio drama, muncul kegemaran siswa dalam berperan mengekspresikan dialog para tokoh pementasan drama

6. Kemampuan bermula, dalam berperan siswa muncul akibat motivasi dan latihan bermain peran dan sandiwara

7. Keterampilan bermain peran dan bersosio drama siswa meningkat 
8. Keterampilan peran siswa juga mengalami peningkatan

9. Partisipasi dalam kelompok, dan kelas siswa dalam pembelajaran sangat menggembirakan

Keberhasilan pembelajaran siswa diatas diatas terlihat dalam partisipasi siswa selama dalam proses pembelajaran, hasil belajar yang diperoleh siswa juga mengalami peningkatan yang sangat berarti, hal ini dapat terlihat perolehan hasil belajar setiap siklus pembelajaran baik aspek kognitif, aspek psikomotor, maupun aspek afektif yang menjadi aspek penilaian dalam setiap siklus pembelajaran.

Berdasarkan pengamatan dan penilaian hasil belajar siswa tiap siklus adalah: I1) Aspek kognitif hasil belajar siswa pada akhir siklus 1 ketuntasan belajar siswa adalah rat-rata $(63,86 \%)$, siklus II ( $68,81 \%$ ), siklus III ( $85,03 \%)$ dengan demikian terjasi kenaikan hasil belajar siswa siklus I ke siklus II ( 4,95\%), siklus II ke siklus III ( $16,22 \%)$, 2) Aspek Psikomotor siklus I ( $79,12 \%)$, siklus II $(83,79 \%)$, sedangkan siklus III ( $92,50 \%)$. Dengan demikian kenaikan hasil belajar antar siklus adalah, siklus I ke siklus II terjadi kenaikan $(4,67 \%)$ sedangkan siklus II kesiklus III mengalami kenaikan ( $8,71 \%$ ), 3) Aspek Afektif hasil belajar siswa ratarata tiap siklus juga mengalami kenaikan yang menggembirakan. Siklus I

$1,07 \%)$, siklus II ( $85,28 \%)$, dan siklus III ( $93,31 \%$ ). Kenaikan siklus I ke siklus II( $4,21 \%$ ) sedangkan kenaikan siklus II ke siklus III adalah ( 8,03\%).

Setelah memahami pembahasan diatas melalui penerapan dalam pembelajaran Bahasa Indonesia, kompetensi kemampuan bersastra, aspek berbicara mengekspresikan dialog para tokoh dalam pementasan drama dapat meningkatkan hasil belajar siswa. Apabila terjadi perubahan tingkah laku dalam pembelajarn, maka pembelajaran dapat dikatakan berhasil.Perubahan tingkah laku dalam pembelajaran ini menerapkan teknik memotivasi, dengan metode bermain peran dan sosio drama..

\section{KESIMPULAN DAN SARAN}

Penelitian ini dapat disimpulkan sebagai berikut:

1. Penerapan pendekatan motivasi, dengan metode bermain peran dan sosio drama dapat memksimalkan atau meningkatkan hasil belajar, mata pelajaran Bahasa Indonesia, komponen kemampuan bersastra aspek berbicara mengekspresikan dialog para tokoh dalam pementasan drama siswa kelas XII IPS 1 semester 1 SMA Negeri 2 Bangko, tahun pelajaran 2014/2015.

2. Penerapan pendekatan motivasi, dengan metode bermain peran dan sosio dapat menimbulkan rasa mengapresiasi seni pementasan drama dalam pembelajaran mata pelajaran Bahasa Indonesia, komponen kemampuan bersastra aspek berbicara kompetensi dasar mengekspresikan dialog para tokoh dalam pementasan drama kelas XII IPS 1 semester 1 SMA Negeri 2 Bangko, tahun pelajaran 2014/2015.

3. Penerapan pendekatan motivasi, dengan metode bermain peran dan sosio drama dapat meningkatkan kerjasama dan saling menghargai antar siswa dalam pembelajaran mata pelajaran Bahasa Indonesia, komponen kemampuan bersastra aspek berbicara kompetensi dasar mengekspresikan dialog para tokoh dalam pementasan drama kelas XII IPS 1 semester 1 SMA Negeri 2 Bangko, tahun pelajaran 2014/2015.

Berdasarkan hasil dan pembahasan maka disarankan: Guru mata pelajaran Bahasa Indonesia dapat menerapkan penerapan motivasi, dengan metode bermain peran dan sosio drama dalam pembelajaran mata pelajaran Bahasa Indonesia, komponen kemampuan bersastra aspek berbicara kompetensi dasar mengekspresikan dialog para tokoh dalam pementasan drama. Sangat perlu diperhatikan tindak lanjut hasil penelitian tindakan kelas ini, dengan harapan agar 
penelitian tindakan kelas betul-betul dapat memaksimalkan atau meningkatkan hasil belajar siswa, khususnya komponen kemampuan bersastra aspek berbicara kompetensi dasar mengekspresikan dialog para tokoh dalam pementasan drama..

\section{DAFTAR PUSTAKA}

Anni, C,. T. 2006. Psikologi Belajar. UPT UNNES Press. Semarang

Anonimus. 2004. Bahasa dan Sasra Indonesia : untuk SMA Kelas XII. Jakarta : Penerbit Erangga.
Dalyono, $M$ dan TIM MKDK IKIP Semarang. 1997. Psikologi Pendidikan. IKIP Semarang Press. Semarang

Hamalik, O. 2003. Prosedur Belajar Mengajar. Bumi Aksara. Jakarta

Nashar, H 2004. Peranan Motivasi dan Kemampuan awal dalam kegiatan Pembelajaran. Delia Press. Jakarta

Soemanto, Wasty. 2003. Psikologi Pendidikan. Rineka Cipta. Malang. 
